\title{
Changes in permanent preservation areas in rural properties of the Santa Catarina state southern plateau according to the laws No. 4,771 and 12,651
}

\author{
Alessandro Bonamigo ${ }^{1}$ Marcos Benedito Schimalski ${ }^{1 *}$ Philipe Ricardo Casemiro Soares $^{1}$ \\ Veraldo Liesenberg ${ }^{1}$ Tamiles Rodrigues de Souza ${ }^{1}$ Tainara Lizandra Schizzi Boesing ${ }^{1}$
}

${ }^{1}$ Departamento de Engenharia Florestal (DEF), Centro de Ciências Agroveterinárias (CAV), Universidade do Estado de Santa Catarina (UDESC), Av. Luiz de Camões, 2090, 88520-000, Lages, SC, Brasil. E-mail: marcos.schimalski@udesc.br. "Corresponding author.

\begin{abstract}
This research aimed to study the parameters of the current and past Brazilian Forest Act based on the Federal Laws No. 4,771 and 12,651 for the determination of the permanent preservation areas (PPA). Water springs and streams for 68 rural properties located at the Santa Catarina State Southern Plateau were considered. Thematic land uselland cover (LULC) as well as PPA maps from the visual interpretation of ortho rectified aerial images were elaborated. The PPA percentage for recovering over consolidated rural areas is directly proportional to both fiscal module size and area of the rural property. Comparing to the Law No. 4,771, there was a significant reduction in the PPA to be recovered on consolidated rural areas. In small rural properties there was an average reduction ranging from $54.6 \%$ to $81.8 \%$. A total of 122,372 hectares (7.6\% of the total area) characterized as PPA in consolidated rural areas can now be used economically.

Key words: Brazilian Forest Act, consolidated rural area, rural property, fiscal module, geo processing.
\end{abstract}

Variação nas áreas de preservação permanente em imóveis rurais do Planalto Sul Catarinense segundo as Leis $n^{0} 4.771$ e 12.651

RESUMO: Estudou-se os parâmetros das Leis Federais n4.771 e 12.651 para a delimitação de PPA de nascentes e cursos d'água em 68 imóveis rurais dos municípios da Região Serrana do Estado de Santa Catarina. Elaboraram-se mapas temáticos da cobertura da terra com as áreas de PPA, a partir da interpretação de imagens aéreas ortorretificadas. Os resultados mostram que o percentual de PPA, a recompor em área rural consolidada, está diretamente relacionado com a área do imóvel e com o tamanho do módulo fiscal do município onde se encontra. Comparando-se com a Lei n-471, houve redução significativa nas PPA a serem recompostas em áreas rurais consolidadas. Em pequenas propriedades rurais, a redução média variou de 54,6 a 81,8\%. Estima-se que 122.372 hectares de terras da região serrana (7,6\% da área), caracterizadas como PPA, em área rural consolidada, podem continuar sendo exploradas economicamente.

Palavras-chave: código florestal brasileiro, área rural consolidada, imóvel rural, módulo fiscal, geoprocessamento.

\section{INTRODUCTION}

May 25, 2012 was the day Congress enacted Federal Law No. 12,651 (BRASIL, 2012), more commonly termed the new Brazilian Forest Act, repealing Federal Law No. 4,771 of September 15, 1965 (BRASIL, 1965) and its changes. Owners of the rural properties recognized that the new law introduced methods that removed the legal uncertainties experienced by the Permanent Preservation Areas (PPA) definition accorded in the earlier law. Law No. 4,771 stated that some types of land use/land cover (LULC) occupation within the existing PPA were considered irregular and; therefore, predisposed to environmental violation (POLÍZIO JR., 2014).
ANTUNES (2013) proposed that the essence of Law No. 12,651 was the recognition and acceptance of the consequences of the faits accomplis viz., the paucity of supervision of the repealed Act, the inability to reach the standards prevalent at that time, and the creation of new environmental requirements without any care for standards compliance. Please refer to MUKAI (2013) and FIORILLO \& FERREIRA (2013) for the historical and legal reflection of the Brazilian Forest Act.

SPAROVEK et al. (2012); however, realized that Law No. 12,651 could raise a few queries regarding environmental sustainability. They indicated that this law could undermine the stringent environmental legislation of Brazil. GARCIA et al. 
(2013) also highlighted the significance of maintaining PPA along the rivers, as well as the legal reserve areas in various biomes to ensure protection of biodiversity.

Law No. 12,651 offered new concepts, including the consolidated rural areas under PPA. Depending on the fiscal module size of a given rural property, the PPA for water streams and natural reservoirs may increase or decrease. However, the major changes Law No. 4,771 made to Law No. 12,651 concerned the lowered percentage of requirements for environmental compliance.

The applicability of Law No. 12,651 with respect to PPA regularization of rural properties compared with Law No. 4,771 can be verified in previous investigations, such as CUPPINI et al. (2012), OKUYAMA et al. (2012) and FARIA et al. (2014). However, questions regarding to the economic, social and environmental impacts of applying Law No. 12,651 in relation to Law No. 4,471 continue to emerge (SPAROVEK et al., 2012). Therefore, the scientific aspects of this research may help to evaluate the applicability and impact of the Law No. 12,651 in the Santa Catarina (SC) southern plateau. This region is well known for its temperate fruit production and wood products industries (FACHINELLO et al., 2011). It will also enable the assessment of the orthorectified images of high spatial resolution currently available from the aerial survey of SC State, performed in 2010 and 2011 (PIAZZA et al., 2016).

So, the present study explored the suitability of the rural properties restricted to the municipalities of the association of municipalities of the Southern Plateau of the SC State (AMURES) to the PPA parameters, over springs and streams in the consolidated rural area under Law No. 12,651 and compared it with those established previously by Law No. 4,471.

\section{MATERIALS AND METHODS}

The site under study extends across the AMURES area, which includes 18 municipalities, covering an area of $16,085.41 \mathrm{sq} . \mathrm{km}$ in total $(1,608,541 \mathrm{ha})$, and accounting for nearly $16.8 \%$ in area of the SC State. The economy of this region is anchored in the beverage and food industry, agriculture, temperate fruit crops, forestry, rural tourism and wood products industries.

At first, a survey was conducted in the Agrarian Planning Division of the Instituto Nacional de Colonização e Reforma Agrária (INCRA) in order to obtain the exact number and area of the registered rural properties for each of the five fiscal module classes (i.e., up to 1,1 to 2,2 to 4,4 to 10 , and $>10$ ). The Special Instruction No. 20 (INCRA, 1980) updated by the Basic Indices 2005 (INCRA, 2007) was selected to search the fiscal module size in each municipality. These data were categorized by number and fiscal module class in accordance to Law No. 12,651 (BRASIL, 2012). In order to estimate the number of rural properties needed for this investigation, taking into account the fiscal module size, a 95\% confidence interval was used with $20 \%$ error margin.

The Union of Rural Workers of Lages as well as technicians transferred the boundaries of the rural properties sampled from forest companies. With the perimeter of the rural properties earmarked for the sampling design, the orthorectified images selected from the 2010 and 2011 aerial survey. Aerial survey images showed a geometric resolution of $0.39 \mathrm{~m}$ (PIAZZA et al., 2016). The surface (MDS) and ground (MDT) digital models were assigned, besides the drainage network extracted from the MDT.

On July 22, 2008 all the rural properties supported pre-existing human occupation. Utilizing photo interpretation over Landsat-5/TM satellite imagery, this pre-existing human occupation was quantified. This method enabled fitting LULC classes such as pastures and agricultural areas into the concept of the consolidated rural area in the rural properties treated in Law No. 12,651. The delimitation of the PPA were selected over springs and streams because of the easy applicability and interpretation from the aerial images.

In order to classify the LULC classes of the rural properties sampled, the GIS application was employed to initiate a project for each property having certain characteristics including the projected coordinate system SIRGAS 2000/UTM 22S zone, which combined the photo interpretation procedures and vectorization of the aerial images. The LULC classes included: a) weir/dam; b) pond, natural lakes, streams and river; c) field (natural grassland, swamp, light poultry); d) agriculture, crops, pasture or temporary cultivation; e) building (house, shed); f) road and firebreaks; g) permanent crops (fruit and apple orchards and others); h) remaining natural forest and secondary forest; i) forest (planted forests of pine, eucalyptus and araucaria etc.).

An interactive evaluation of the drainage network and the springs for each rural property sampled was done with a mesh drainage, extracted from the DTM. Law No. 12,651 defines PPA only over springs with permanent flux of water. However, continuous monitoring is essential in order to correctly identify these springs in the field. Unfortunately, due 
to limited resources available we consider only the visual interpretation of the aerial images and DTM.

In like manner Law No. 4,771, which demarcates the PPA water courses up to the highest level, also requires continuous field monitoring, particularly during the rainy season. Law No. 12,651 defines the PPA from the edge of the channel of the regular bed of the watercourse. In this study, the apparent watercourse edge was visually identified in the images. Drainage network vectors from the State Government were also considered.

This vector set is a part of the official maps of the State of SC, based on which, public policies on water resources management are drawn up. It is from this database, that the parameters listed in Law Nos. 4,771 and 12,651 have been established. However, some limitation in the methods linked to the sustainability of water sources and proper delimitation of the river channels may exist. However, this is the identical methodology incorporated in the Rural Environmental Registry (CAR).

Parameters delimiting the marginal PPA over streams according to Law No. 4,771, and identified in the rural properties were $30 \mathrm{~m}$ for streams less than $10 \mathrm{~m}$ in width, and $50 \mathrm{~m}$ for those rivers having $10-50 \mathrm{~m}$ width. For spring a $50 \mathrm{~m}$ radius was used.

Law No. 12,651 related to the PPA over streams in the consolidated rural areas includes a marginal strip where recovery is compulsory. This range starts with $5 \mathrm{~m}$ (i.e., for rural properties having up to one fiscal module) up to half the river width considering at least a $30 \mathrm{~m}$ width and up to a maximum of $100 \mathrm{~m}$ (for rural properties having more than 10 fiscal modules). No lakes or natural water reservoirs were reported. Yet, perennial springs in the consolidated rural areas must recover its surroundings up to $15 \mathrm{~m}$ radius.

In order to identify the LULC class inside PPA according to the Laws, the following GIS methods were used: a) overlap and intersection of polygons; b) calculation of the areas of the new polygons; c) creating tables in order to quantify the conflict between the PPA and LULC class; and d) drawing up a summary table for the total area of the selected rural property.

During the statistical analysis, the overlap percentage was calculated by analyzing the LULC class within PPA in the two scenarios, keeping in line the parameters mentioned in the Laws Nos. 4,771 and 12,651. The data analyzed for the rural properties included: a) PPA percentage of the total area of the property; b) PPA percentage to be recomposed in the consolidated rural area presently occupied as grasslands, fruit crops, farming and planted forest over the total area of the rural property; c) Changes in the PPA according to Law No. 4,771 for those in a consolidated rural area based on Law No. 12,651. Descriptive statistics as well as both Shapiro Wilks and Kolmogorov-Smirnov tests were also used to verify data distribution.

Percentage of PPA areas not bounded by recovery and that can still be used for agriculture was determined for each of the five fiscal module classes. An overall estimate of these percentages was performed over the entire AMURES region.

\section{RESULTS AND DISCUSSION}

On analyzing the data of the rural properties according to INCRA legislation, it became clear that among the 18 municipalities constituting the region of the AMURES, 15 have a fiscal module area of 20 hectares, one has 22 hectares and two have 24 hectares. Of the properties registered 28,044 properties were present in the study area $\left(16,085.41 \mathrm{~km}^{2}\right)$. Those defined as small rural property (up to 4 fiscal modules) comprise $83 \%$ of the property and occupy $31 \%$ of the total area. Calculation of the sample size resulted in 68 rural properties for the five fiscal module classes.

Results from the classification of the aerial images are thematic maps of the LULC classes and its overlapping with the PPA, as shown in figure 1A. Parameters of both the Laws are analyzed as shown in figure $1 \mathrm{~b}$. In table 1 , the average percentages of the PPA in the sampled properties are listed according to the five fiscal module classes. Data normality is revealed by the statistical tests.

In the real estate of one fiscal class module, under Law No. 4,771, the average percentage of PPA relative to the total area of the rural properties was $36.8 \%$, while according to Law No. 12,651, the average percentage of PPA required to be recomposed in the consolidated rural area of the total area was $7.2 \%$ (Table 1).

Table 1 showed that in the rural properties over 1 and up to 2 fiscal modules under Law No. 4,771 the average percentage of PPA compared with the total area of the property was $33.4 \%$. These results are marginally higher than the ones observed by OKUYAMA et al. (2012), wherein familybased properties with an average area of 10.26 ha in the state of Parana were evaluated. The average percentage of PPA was $20 \%$ of the total area of the property. In the present paper, under Law No. 12,651, the average percentage of PPA to be recomposed in 


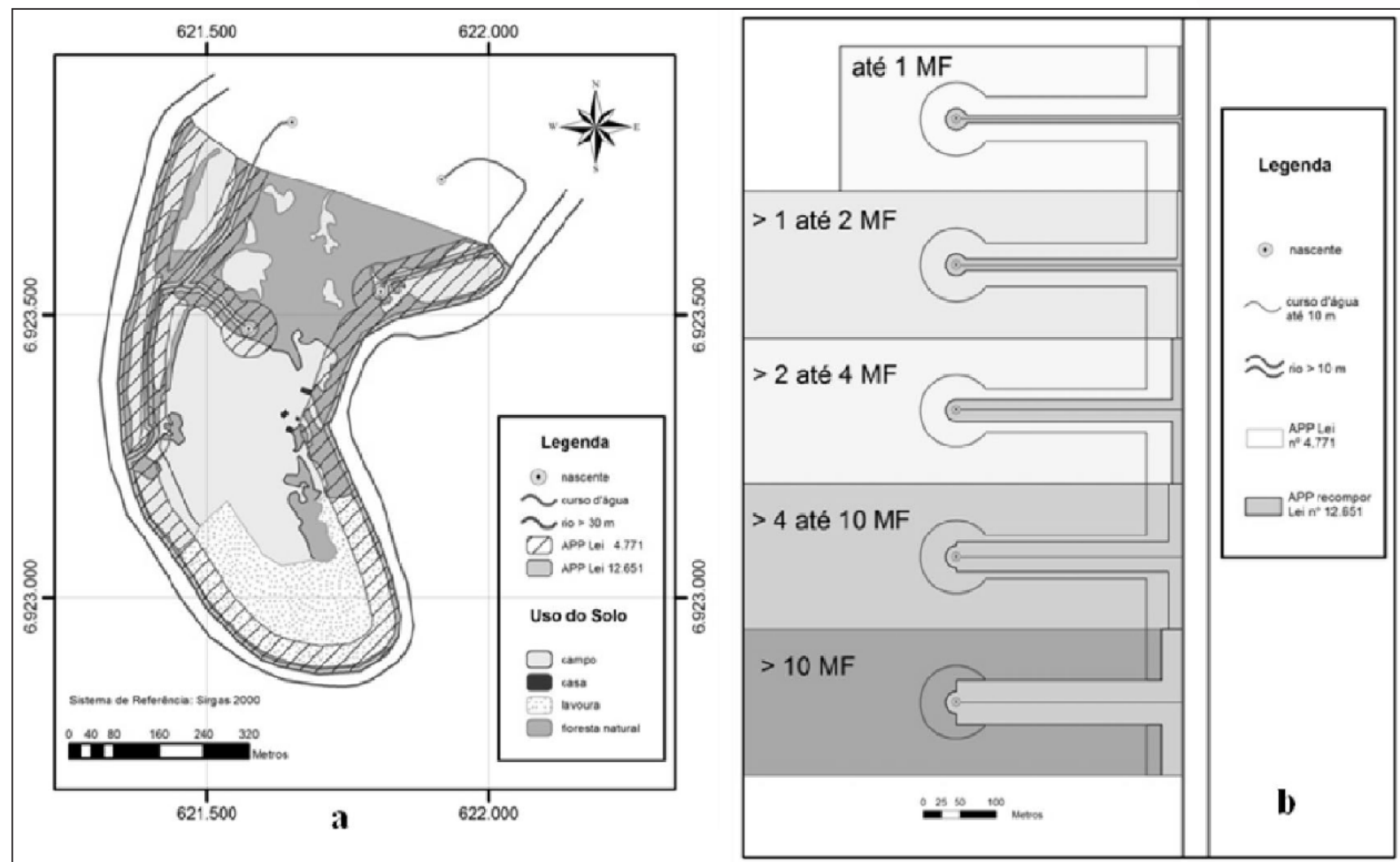

Figure 1 - (a) Thematic map of the Rural Property No. 7, from the 1 up to 2 fiscal modules class. (b) Effects of applying both Law Nos. 4,771 and 12,651 in the delimitation of the permanent preservation areas (PPA) and PPA to be recomposed in the consolidated rural area, respectively.

the consolidated rural area on the total area of the property was $9.0 \%$. The uniqueness of the AMURES with respect to LULC occupation, including fiscal module size, are the main reasons for the variations observed between the results in these two studies.

Rural properties greater than 2 up to 4 fiscal modules (Table 1) under Law No. 4771 showed on average that the percentage of PPA in relation to the total area of the property was $38.1 \%$. This result is higher than the one reported by CUPPINI et al. (2012) which was $25.04 \%$ for a rural property having a size of 2.51 fiscal module in the north of the state of Rio Grande do Sul. Law No. 12,651 stated that the average percentage of PPA to be recomposed in the consolidated rural area of this study was $17.2 \%$, a value slightly higher than the reported $15.97 \%$ by CUPPINI et al. (2012).

Rural properties having above 4 up to 10 fiscal modules, according to Law No. 4,771, showed an average percentage of PPA in relation to the total area of the property of $36.1 \%$. This is a higher percentage than that recorded by FARIA et al. (2014) which was $23.16 \%$ on a rural property of
9.5 fiscal modules located in state of São Paulo (SP). Under Law No. 12,651, the average percentage of PPA to be recomposed in the consolidated rural area of the properties analyzed in this study was $20.9 \%$ (Table 1). This value is much higher than the $8.11 \%$ which was reported by FARIA et al. (2014).

Real estate extending to rural properties having more than 10 fiscal modules, under Law No. 4,771, reported an average PPA percentage of 26.5 in relation to the total area of the properties. These results are higher than the results reported by FARIA et al. (2014) which was $20.97 \%$ for a rural property of 54.1 modules in the state of SP. The average percentage of PPA to be recomposed in the consolidated rural area was $22.2 \%$ under Law No. 12,651 , as shown in table 1 , as against the value of $17.81 \%$ recorded by FARIA et al. (2014).

On evaluating the averages of the delimitation of PPA among the five fiscal module classes, under Law 4,771 perspective, the differences may imply that the increased in area of the rural property do not result in the increase in PPA, in the same proportion. With respect to the PPA to 
Table 1 - Areas and percentage of the average permanent preservation areas (PPA) for the properties sampled for the class tax module according to Law Nos. 4,771 and 12,651 and the average variation in percentage.

\begin{tabular}{|c|c|c|c|c|c|c|}
\hline \multirow{2}{*}{$\begin{array}{l}\text { Fiscal module } \\
\text { Class }\end{array}$} & \multirow{2}{*}{$\begin{array}{l}\text { Size of the rural } \\
\text { property ha }\end{array}$} & \multicolumn{2}{|c|}{ PPA (LawNo. 4,771) } & \multicolumn{2}{|c|}{$\begin{array}{l}\text { PPAto be recomposed LawNo. } \\
\qquad 12,651\end{array}$} & \multirow{2}{*}{$\begin{array}{l}\text { Variation in \% between Laws } \\
\text { Nos. } 12,651 \text { e } 4,771\end{array}$} \\
\hline & & ha & $\%$ & ha & $\%$ & \\
\hline up to 1 & 9.06 & 3.30 & $36.8 \%$ & 0.64 & $7.2 \%$ & $-81.8 \%$ \\
\hline$>1$ to 2 & 32.09 & 10.97 & $33.4 \%$ & 2.93 & $9.0 \%$ & $-73.1 \%$ \\
\hline$>2$ to 4 & 56.53 & 21.16 & $38.1 \%$ & 9.62 & $17.2 \%$ & $-54.6 \%$ \\
\hline$>4$ to 10 & 129.98 & 44.46 & $36.1 \%$ & 25.84 & $20.9 \%$ & $-41.9 \%$ \\
\hline$>10$ & 522.70 & 124.00 & $26.5 \%$ & 106.70 & $22.2 \%$ & $-15.2 \%$ \\
\hline
\end{tabular}

be recomposed in the consolidated rural areas in accordance with Law No. 12,651, differences were observed also within each fiscal module class. This crescent variation is explained by the increased parameters in the definition of the PPA to be recomposed in the consolidated rural area, according to the increasing of the rural property size.

There are significant changes in terms of surface reduction between the PPA defined by Law No. 4,771 in terms of areas to be recomposed in the consolidated rural areas defined by Law No. 12,651. Similarly, the protective strip may vary significantly, as seen in figure $1 \mathrm{~b}$. The implication of such changes, from an environmental point of view, are suggested for future studies, including the selection of rural properties in other parts of the country, because the minimum fiscal module size may vary among the municipalities of the federation.

The reduction of PPA in the consolidated rural area is evidently beneficial to the owners or possessors of the rural properties for the first three classes, i.e., up to 4 fiscal module class. Reductions in
PPA were in order $81.8 \%, 73.1 \%, 54.6 \%, 41.9 \%$ and $15.2 \%$, respectively, considering from the smaller to the biggest fiscal module class (Table 1). Therefore, the reduction in the PPA to be recomposed decreases with the decreasing of the fiscal module class.

In rural properties where the PPA to be recomposed in the consolidated rural areas whose LULC were classified as grasslands, fruit crops, farming and forestry, directly involved with both agriculture and forest sector, the PPA average percentage in the classes ranged from $2.9 \%$ to $11.0 \%$ (Table 2). Considering this scenario, it was evident that as the number of fiscal module increased, the percentage of the PPA that could be used decreased, in light of the concept of the consolidated PPA areas according to Law No. 12,651. Table 2 shows the analysis of the average percentage of the consolidated area in relation to the rural property area. The percentage values are $16.7 \%, 13.5 \%, 12.8 \%$, $10.4 \%$ and $2.5 \%$, from the smaller to the highest fiscal module class interval, respectively.

Extrapolating these percentages to the context of AMURES, 122,372 ha of PPA can be

Table 2 - Average values of the permanent preservation areas (PPA) in consolidated areas according to Law Nos. 4,771 and 12,651 and not bound by recomposition according to Law No. 12,651.

\begin{tabular}{|c|c|c|c|c|c|c|c|c|}
\hline \multirow[t]{2}{*}{$\begin{array}{l}\text { Fiscal } \\
\text { class }\end{array}$} & \multirow{2}{*}{$\begin{array}{c}\text { Mean Size } \\
\text { ha }\end{array}$} & \multirow{2}{*}{$\begin{array}{c}\text { Under PPA Law } \\
\text { No. } 4,771 \\
\text { ha }^{1}\end{array}$} & \multicolumn{2}{|c|}{$\begin{array}{l}\text { Under PPA Law } \\
\text { No. } 12,651\end{array}$} & \multirow{2}{*}{$\begin{array}{c}\text { Total Area of AMURES } \\
\text { ha }\end{array}$} & \multicolumn{3}{|c|}{$\begin{array}{c}\text { Can continue with activities } \\
\text { Law No. } 12,651\end{array}$} \\
\hline & & & $\mathrm{ha}^{2}$ & $\%$ & & $\mathrm{ha}^{3}$ & $\%$ & $\mathrm{ha}^{4}$ \\
\hline up to 1 & 9.06 & 1.73 & 0.22 & 2.9 & 114,143 & 1.51 & 16.7 & 19,019 \\
\hline$>1$ to 2 & 32.09 & 5.37 & 1.05 & 3.3 & 139,402 & 4.33 & 13.5 & 18,798 \\
\hline$>2$ to 4 & 56.53 & 11.47 & 4.25 & 7.5 & 239,278 & 7.22 & 12.8 & 30,578 \\
\hline$>4$ to 10 & 129.98 & 26.86 & 13.34 & 11.0 & 331,442 & 13.52 & 10.4 & 34,479 \\
\hline$>10$ & 522.70 & 71.04 & 58.04 & 10.5 & 784,276 & 13.00 & 2.5 & 19,498 \\
\hline Total & & & & & $1,608.541$ & & & 122,372 \\
\hline
\end{tabular}

${ }^{1}$ PPA according to Law No. 4,771. ${ }^{2}$ PPA classified as consolidate rural area under Law No.12,651. ${ }^{3}$ PPA differences between Law Nos. 4,771/1965 and $12,651 .{ }^{4}$ Extrapolation to the entire AMURES area. 
used regularly for agriculture and/or forest activities. According to Law No. 4,771 these areas were considered illegal and; therefore, predisposed to environmental violation. This estimate represents $7.6 \%$ of the total area of the region.

\section{CONCLUSION}

When compared with Law No. 4,771, there is a significant reduction in the delimitation of the PPA to be recomposed because of the concept of consolidated rural areas introduced by Law No. 12,651. However, this reduction is directly proportional to the fiscal module size of the rural property. On extrapolating the results obtained to the AMURES region, $7.6 \%$ of the total area of the PPA in consolidated rural areas can be used for both agriculture and forest activities. This study avoided socio-economic aspects, which could be the subject of future research by integrating Population Census data from the Instituto Brasileiro de Geografia e Estatística (IBGE).

\section{REFERENCES}

ANTUNES, P.B. Comentários ao novo Código Florestal. São Paulo: Atlas, 2013. 345p.

BRASIL. Lei $\mathrm{n}^{\circ} 4.771$, de 15 de setembro de 1965. Institui o novo código Florestal. Diário Oficial [da] República Federativa do Brasil, Brasília, DF, 16 set. 1965. Available from: <http://www.planalto.gov.br/ccivil_03/leis/14771.htm>. Accessed: Apr. 14, 2014

BRASIL. Lei $\mathrm{n}^{\circ}$ 12.651, de 25 de maio de 2012. Dispõe sobre a proteção da vegetação nativa. Diário Oficial [da] República Federativa do Brasil, Brasília, DF, 28 maio, 2012. Available from: <http://www.planalto.gov.br/ccivil_03/_ato2011-2014/2012/lei/ 112651.htm>. Accessed: Apr. 14, $20 \overline{14}$.

CUPPINI, D.M. et al. Análise das áreas de preservação permanente em uma propriedade rural sob o enfoque do código florestal federal (Brasil 1965) e Lei 12.727/2012. Revista Perspectiva, v.36, n.135, p.41-51, 2012.

FACHINELLO, J.C. et al. Situação e perspectivas da fruticultura de clima temperado no Brasil. Revista Brasileira de Fruticultura, v.33, p.109-120, 2011. Available from: <http://dx.doi.org/10.1590/ S0100-29452011000500014>. Accessed: Jan. 16, 2015. doi: $10.1590 / \mathrm{S} 0100-29452011000500014$
FARIA, L.C. et al. Reflexos das alterações no Código Florestal Brasileiro em Áreas de Preservação Permanente, de duas propriedades rurais em Itu e Sarapuí, SP. Revista Ambiente \& Água, v.9, n.3, p.559-568, 2014. Available from: <http://dx.doi. org/10.4136/ambi-agua.1354>. Accessed: Jan. 16, 2015. doi: 10.4136/ambi-agua. 1354

FIORILLO, C.A.P.; FERREIRA, R.M. Comentários ao "Código" Florestal. São Paulo: Saraiva, 2013. 179p.

GARCIA, L.C. et al. Restoration challenges and opportunities for increasing landscape connectivity under the new Brazilian forest act. Natureza \& Conservação, v.11, n.2, p.181-185, 2013. Available from: <http://dx.doi.org/10.4322/natcon.2013.028>. Accessed: Jan. 16, 2015. doi: 10.4322/natcon.2013.028.

INCRA. Instrução Especial nº 20, de 28 de maio de 1980. Estabelece o Módulo Fiscal de cada Município, previsto no Decreto n ${ }^{\circ} 84.685$ de 6 de maio de 1980. Diário Oficial [da] República Federativa do Brasil, INCRA, Brasília, DF, 12 jun. 1980. Available from: $<$ http://www.incra.gov.br/media/institucional/legislacao/ atos internos/instrucoes/instrucao especial/IE20 280580.pdf $>$. Accessed: Jul. 16, 2014.

INCRA. Índices Básicos 2005. Brasília, DF, 12 abr. 2007. Available from: <http://www.incra.gov.br/estrutura-fundiaria/ regularizacao-fundiaria/indices-cadastrais/file/113-indicesbasicos-2005-12042007>. Accessed: Jan. 16, 2015

MUKAI, T. O novo código florestal. "Anotações à Lei no 12.651 , de 25 de maio de 2012, com as alterações da Lei n ${ }^{\circ} 12.727$, de 17 de outubro de 2012". Rio de Janeiro: Forense, 2013. 162p.

OKUYAMA, K.K. et al. Adequação de propriedades rurais ao Código Florestal Brasileiro: estudo de caso no estado do Paraná. Revista Brasileira de Engenharia Agrícola e Ambiental, v.16, n.9, p.1015-1021, 2012. Available from: <http://dx.doi. org/10.1590/S1415-43662012000900013>. Accessed: Jan. 16, 2015. doi: 10.1590/S1415-43662012000900013.

PIAZZA, G.A. et al. Object-oriented and pixel-based classification approaches to classify tropical successional stages using airborne high-spatial resolution images. GIScience and Remote Sensing, v.53, p.206-226, 2016. Available from: <http://dx.doi.org/10.1 080/15481603.2015.1130589>. Accessed: Jan. 16, 2015. doi: $10.1080 / 15481603.2015 .1130589$

POLÍZIO JÚNIOR, V. Novo código florestal. 2.ed. São Paulo: Rideel, 2014. 321p.

SPAROVEK, G. et al. The revision of the Brazilian Forest Act: increased deforestation or a historic step towards balancing agricultural development and nature conservation? Environmental Science \& Policy, v.16, p.65-72, 2012. Available from: <http:// dx.doi.org/10.1016/j.envsci.2011.10.008>. Accessed: Jan. 16, 2015. doi: 10.1016/j.envsci.2011.10.008 